\title{
Pengembangan aplikasi tes keterampilan sepakbola berbasis web
}

\author{
Eko Supriyono \\ SMP Negeri 6 Yogyakarta. Jalan R. W. Monginsidi No. 1, Yogyakarta, 55233, Indonesia \\ * Corresponding Author. Email: ekosupriyono_27@yahoo.com \\ Received: 27 January 2017; Revised: 8 February 2018; Accepted: 20 April 2018
}

\begin{abstract}
Abstrak
Penelitian bertujuan untuk menghasilkan produk Aplikasi Tes Keterampilan Sepakbola (Soccer Skill Test) Berbasis Web dan buku panduan. Penelitian ini merupakan penelitian pengembangan, melalui 5 tahapan, yaitu: (1) studi pendahuluan dan pengumpulan informasi, (2) desain produk awal, (3) validasi ahli/revisi, (4) ujicoba lapangan skala kecil/revisi, (5) uji coba skala besar dan produk akhir. Subjek penelitian adalah ahli materi, ahli media, dan pelatih Sekolah Sepakbola di Daerah Istimewa Yogyakarta. Instrumen berupa angket dan observasi. Hasil penelitian yaitu Aplikasi Tes Keterampilan Sepakbola (Soccer Skill Test) Berbasis Web yang berisi menu pokok yaitu: (1) Menu Home, (2) Menu Panduan Tes dan Konversi Hasil Tes Keterampilan Sepakbola yang bisa di input secara individu maupun data Excel, (3) Aplikasi tes terdiri dari 7 item tes keterampilan sepakbola yaitu: tes dribbling, passing-control, shooting, passing lambung, juggilng, heading, (4) Menu contak admin.
\end{abstract}

Kata Kunci: perancangan aplikasi, tes keterampilan sepakbola, pelatih;

\section{Developing web-based soccer skills test application}

Abstract

This research aimed to produce web-based soccer skills test application. This research belonged to research and development with model of procedural descriptive that outlined the steps which should be followed to create a product. The development of web-based soccer skills test application were done in 5 steps, namely: (1) undertaking pre-study and information collection, (2) developing design of initial product, (3) expert validation and revision, (4) small-scale field test and product revision, (5) large-scale field test and final product. The subjects of this research and development were material expert, media expert and coaches of soccer school of Yogyakarta Province $(D I Y)$. The instrument of this research were questionnaire and observation. The result of this research was a web-based soccer skills test application was produced that contained main menu, namely: (1) Home, (2) menu of test guide and the conversion of result of soccer skill test which could be inputted individually or by Excel data, (3) the test application consisted of 7 items of soccer skills, that were: test of dribbling, passing-control, shooting, long-passing, juggling, heading, (4) тепи of administrator's contact.

Keywords: application development, soccer skills test, soccer coaches

How to Cite: Supriyono, E. (2018). Pengembangan aplikasi tes keterampilan sepakbola berbasis web. Jurnal Keolahragaan, 6(1), 38-47. doi:http://dx.doi.org/10.21831/jk.v6i1.12764

http://dx.doi.org/10.21831/jk.v6i1.12764

\section{PENDAHULUAN}

Bidang olahraga menjadi salah satunya dalam sub ilmu dalam pendidikan, perkembangan ini ditandai dengan munculnya inovasi-inovasi pada model-model latihan maupun sarana dan prasarana yang mendukung peningkatan kemampuan pemainnya. Inovasi model latihan maupun peralatan berguna untuk mendukung kegiatan olahraga baik dari sisi latihan, pertandingan, maupun evaluasi demi mencapai tujuan yang ditetapkan. Senada dengan hal tersebut, Deputi IV Kemenpora Djoko Pekik Irianto (Rohmat, 2014) menyatakan bahwa "IPTEK telah menjadi ujung tombak bagi olahraga di negara-negara maju dan Implementasi IPTEK bisa dimulai sejak pembibitan, pelatihan usia dini, yunior, dan seterusnya. Intinya, untuk 
percepatan peningkatan prestasi ada empat pilar mulai sarana dan prasarana dan salah satunya adalah implementasi IPTEK.

Sinergi Implementasi IPTEK yang linier dengan sumber daya manusia yang unggul di bidang olahraga sangat diharapkan dapat menjadi sebuah ramuan yang ampuh demi mencapai sebuah tujuan, yaitu prestasi maksimal. Hal ini semakin menjadi tantangan bagi civitas akademika khususnya dalam bidang olahraga untuk bekerja secara maksimal. Dilihat dari perkembangan teknologi komputer saat ini, tidak hanya dari sisi perangkat keras saja tetapi juga dari sisi perangkat lunak. Contoh perkembangan pada sisi perangkat lunak yaitu munculnya berbagai aplikasi yang berguna bagi masyarakat. Mulai dari aplikasi web, multimedia, sampai dengan aplikasi permainan yang kini banyak diminati.

Salah satunya adalah peranan media komputer dengan berbagai software aplikasi untuk meningkatkan penyampaian suatu informasi. Informasi adalah suatu sumber daya yang dibutuhkan dalam mengelola bisnis. Hampir semua pekerjaan dapat dibantu dengan teknologi yang diciptakan oleh manusia, sehingga manusia dapat mempunyai daya guna dan tepat guna yang mampu mendorong kemajuan suatu bidang atau usaha.

"Perhaps the most significant development in this movement was the development of the World Wide Web (the web). As the web has moved from comparatively static Web 1.0 content through the development of Web 2.0 social media applications to the beginning of Web 3.0 practices, there have been significant changes in how humans use computer technology to interact with one another" (Rosandich, 2011, p.3).

Pernyataan tersebut mempunyai arti bahwa perkembangan yang paling signifikan dalam era ini adalah pengembangan dari World Wide $W e b$ (web). Web telah pindah dari relatif statis Web 1.0 konten melalui pengembangan Web 2.0 aplikasi media sosial untuk awal 3,0 praktik Web telah terjadi perubahan signifikan dalam bagaimana manusia menggunakan teknologi komputer untuk berinteraksi satu sama lain. Web browser merupakan salah satu jenis perangkat yang memudahkan orang untuk mengakses dari tempat manapun dengan melalui sambungan internet. Menurut McLeod (2008, p.65) Web browser adalah suatu perangkat lunak yang di desain untuk mencari dan membaca file di internet dalam format HTML atau Hyper Text
Markup Language. Sebuah halaman web biasanya berupa dokumen yang ditulis dalam format HTML (Hyper Text Markup Language), yang selalu bisa diakses melalui HTTP, yaitu sebuah protokol yang menyampaikan informasi dari server website untuk ditampilkan kepada para pemakai melalui web browser. Semua publikasi dari website tersebut dapat membentuk sebuah jaringan informasi yang sangat besar.

Peran komputer yang teritegrasi dengan sambungan internet kini pun semakin meluas, tidak hanya menjadi alat bantu hitung, tapi juga menjadi alat bantu penyelesaian masalah-masalah yang dihadapi manusia. Sistem yang terintegrasi dalam komputer hari ini memungkinkan menyimpan data dengan jumlah besar (database), mencari data yang tersimpan dengan waktu singkat, bahkan ada juga komputer sebagai alat pemberi pertimbangan dalam menentukan kebijakan. Semakin cerdas sistem yang dibuat dan semakin ditingkatkan level penanganan informasi masukannya, semakin aktif peranan yang dimainkan oleh komputer dengan kecanggihannya.

Berlandaskan hal tersebut, dalam bidang olahraga khususnya sepakbola saat ini sudah tidak terpisahkan dengan sistem perangkat lunak berbasis web, sebagai contoh mulai dari level klub sampai dengan kementrian pemuda dan olahraga sudah mempunyai situs web khusus yang digunakan sebagai alat untuk publikasi informasi. Contoh lain adalah tim-tim raksasa dari benua Eropa yang mempunyai penggemar/ fans yang sangat besar yaitu Real Madrid dari Spanyol dan Manchester United yang menggunakan kecanggingan sistem Web sebagai wahana berinteraksi dengan fans di seluruh dunia. Peran inilah yang diharapkan dapat meningkatkan kualitas dari bidang olahraga sepakbola sebagai olahraga yang paling diminati di seluruh penjuru dunia. Sepakbola sebagai cabang olahraga yang paling populer di dunia menjadikannya ladang garapan dari berkembanganya IPTEK. Seperti halnya yang diungkapkan oleh Reilly \& Williams (2003) (Barreira, 2013, p.47) menyatakan "Soccer has been a good example of the translation of cutting-edge research into practical applications at the professional level". Dapat diartikan sepakbola telah menjadi contoh yang baik dari terjemahan Penelitian mutakhir dalam aplikasi praktis di tingkat profesional, dengan kata lain cabang olahraga sepakbola profesional merupakan tempat dengan banyaknya penelitian pengembangan teknologi mutakhir 
termasuk dalam bentuk sistem perangkat lunak berbasis web.

Pada hakikatnya sepakbola adalah permainan yang dimainkan oleh dua tim yang masing-masing beranggotakan 11 orang. Masingmasing tim mempertahankan sebuah gawang dan mencoba menjebol gawang lawan. Sepakbola adalah suatu permainan yang dimainkan oleh dua regu yang masing-masing regu terdiri dari sebelas pemain termasuk seorang penjaga gawang Luxbacher (2011, p. 20). Permainan ini mempunyai gerakan yang sangat kompleks, sehingga menuntut pemain sepakbola mempunyai fisik serta keterampilan yang baik agar dapat bekerja sama meraih prestasi secara maksimal. Salah satu usaha yang dilakukan untuk mencapai sebuah prestasi masksimal dapat dilakukan melalui latihan yang teratur, terprogram dan terukur. Sebuah peak performance (puncak prestasi) dalam olahraga sepakbola tidak tercipta secara kebetulan, melainkan dari hasil dari persiapan atlet yang sangat cermat, berdasarkan program latihan terorganisir secara sangat rinci, direncanakan bertahap, objektif dan berkesinambungan (Harsuki, 2003, p.308). Pembinaan olahraga prestasi memiliki tahapan pembinaan, yaitu (1) tahap pemassalan, (2) tahap pembibitan, (3) tahap pembinaan prestasi. Banyak cara yang dilakukan dalam mencari bibit potensial untuk pembinaan olahraga. Pembibitan dimulai dari usia dini diharapkan menjadi langkah awal proses pembinaan menuju prestasi olahraga. Perkembangan keterampilan dan kemampuan berolahraga dibagi menjadi tiga kelompok, yaitu: (1) kelompok praktis dimulai olahraga, (2) kelompok umur pengkhususan, dan (3) kelompok untuk jangka penampilan tertinggi (Bompa, 2009, p.64).

Berkaca dari tahap pembinaan cabang olahraga sepakbola, tes dan pengukuran yang merupakan dasar untuk menentukan bibit atlet, monitoring perkembangan kemampuan pemain dan evaluasi untuk merencanakan program. Tes dan Pengukuran hakikatnya merupakan alat ukur untuk memperoleh data/informasi. Sedangkan pengukuran disini bermaksud proses untuk memperoleh data. Data ini hakekatnya tidak akan bermakna bila tidak ada tindakan evaluasi. Dari hasil evaluasi didapatkan suatu kesimpulan untuk membuat keputusan dan alternatif tindakan berdasarkan data. Bompa (1994, p.85) menyatakan bahwa tes adalah instrumen unjuk kerja individu, sedangkan penilaian merupakan proses untuk menentukan status seseorang sesuai kriteria yang dipakai. Dengan demikian tes adalah bagian integral dari pengukuran, sehingga tes dan pengukuran adalah sesuatu yang tidak dapat dipisahkan. Pengukuran menyediakan sarana yang dapat digunakan untuk mengumpulkan informasi yang diperlukan. Seperti halnya dalam cabang olahraga sepakbola yang membutuhkan data perkembangan pemain. Ditambahkah oleh Barreira (2013, p.48) "These should provide coaches with valuable information to optimise individual and team training programmes". Bahwa pemahaman tentang kinerja olahraga harus menyediakan pelatih dengan informasi berharga untuk mengoptimalkan program pelatihan individu dan tim. Hal ini menjadi amat penting bagi pelatih untuk melihat perubahan kemampuan atau peningkatan atlet setelah mengikuti program latihan dan sebagai bahan evaluasi untuk menentukan perencanaan program ke depannya.

Instrumen merupakan sebuah alat ukur yang vital dibutuhkan dalam proses mengukur kemampuan individu. Dalam sepakbola sendiri instrumen untuk mengukur keterampilan atau kecakapan pemain sepakbola sudah banyak tersedia, mulai dari tes sirkuit yang berupa suatu rangkaian untuk mengetahui proporsi tubuh, fisik dan bermain seperti David Lee (ASF) yang merupakan suatu rangkaian tes sirkuit yang bertujuan untuk mengukur keterampilan bermain sepakbola untuk pemain muda yang terdiri dari teknik dribbling, passing, dan shooting, atau tes yang mengarah ke satu-persatu teknik tertentu seperti passing lambung, juggling, dan shooting yang dikembangkan oleh Bobby Charlton dan tes dribbling, passing-control dan heading dikembangkan Nurhasan.

Berdasarkan hasil observasi di lapangan pada saat tes seleksi minat dan bakat istimewa kelas khusus olahraga Daerah Istimewa Yogyakarta, semua pelatih Kelas Khusus Olahraga (KKO) yang berada di Daerah Istimewa Yogyakarta yaitu SMP Negeri 13 Yogyakarta, SMP Negeri 1 Kalasan, SMP Negeri 3 Sleman, dan SMP Negeri 2 Tempel. Tingkat SMA adalah SMA Negeri 1 Seyegan, SMA Negeri 2 Ngaglik, SMA Negeri 4 Yogyakarta, SMA Negeri 2 Playen dan SMA Negeri 1 Sewon menggunakan data tes dan pengukuran yang terdiri atas Pengukuran Anthopomeri untuk melihat komposisi tubuh, Tes Fisik yang terdiri atas berbagai macam komponen biomotor dalam cabang sepakbola, dan Tes Kecabangan sepakbola yaitu tes David Lee (Australian Soccer Federation) untuk tingkat calon siswa SMP dan David lee pengembangan dari Subagyo Iriyanto 
untuk siswa SMA, serta tes pengamatan pada saat pemain melakukan game dalam mengetahui kemampuan awal (pretest) pemain dalam tahap menyeleksi calon pemainnya dan menggunakan kembali sebagai tahap evaluasi setelah menjalani program latihan terprogram dari pelatih. Di sisi lain dari hasil observasi di lapangan kepada 33 pelatih, Sekolah Sepakbola (SSB) hanya beberapa yang menggunakan gabungan dua metode tersebut, dari hasil survei menunjukan $57 \%$ KKO dan SSB menggunakan gabungan metode tes dan pengamatan pada saat pemain bermain, sedangkan $43 \%$ SSB hanya menggunakan metode pengamatan saja. Penggunaan pengamatan saja semuanya berasal dari SSB. Metode tersebut akan lebih baik apabila dilengkapi dengan adanya data ilmiah yang berasal dari tes dan pengukuran secara individu sebagai langkah dasar dan bahan evaluasi dalam mengetahui kemampuan pemain tersebut.

Selanjutnya data hasil survei yang dilakukan oleh peneliti kepada 33 pelatih sekolah sepakbola yang ada di wilayah kota Yogyakarta dan Kabupaten Sleman memperlihatkan bahwa sebanyak $100 \%$ pelatih dapat mengoperasikan komputer dan smartphone, sebanyak $100 \%$ pelatih dapat mengakses internet melalui komputer dan smartphone, sebanyak $100 \%$ pelatih menggunakan komputer, neetbook, dan smartphone dalam membantu pengolahan data tes, sebanyak $87 \%$ pelatih menyatakan tidak kesulitan mengolah data sebagian tes keterampilan sepakbola, sebanyak $97 \%$ melakukan tes dan pengukuran pretest terhadap siswa pada saat seleksi atau sebelum mengikuti program latihan, sebanyak $97 \%$ pelatih melakukan tes dan pengukuran posttest keterampilan siswa/pemain setelah siswa selesai mengikuti program latihan, sebanyak $100 \%$ pelatih menyatakan sangat perlu pengembangan seperti aplikasi konversi data hasil tes kedalam tabel untuk membantu memudahkan konversi (pengkategorian) hasil tes, sebanyak $100 \%$ pelatih menyatakan setuju dengan pengembangan aplikasi ini, sehingga di masa depan akan tercipta norma baku keterampilan sepakbola sesuai dengan tingkatan usia.

Setelah penulis menganalisis hasil survei kepada pelatih dan mengamati semua item tes keterampilan tes sepakbola yang tersedia, hal ini menjadi tolak ukur bahwa kebutuhan akan tes ini sangat tinggi dan dilandasi dengan tes yang tersedia masih ada kelemahan yaitu dalam hal mengolah atau mengkonversi skor data hasil tes ke dalam kategori kemampuan. Pembuatan kesimpulan hasil tes masih berupa pencocokan tabel norma secara manual, bahkan banyak item tes yang belum terdapat norma pengkategorian kemampuan pemain, seperti tes dribbling, passing, juggling, dan heading. Hal tersebut menjadi kurang efektif dan efisien, terlebih lagi dengan belum adanya norma baku yang semakin membuat bingung para pelatih dalam menentukan kemampuan pemain. Adanya norma baku dari masing-masing item tes akan lebih memudahkan pelatih dan juga pemain itu sendiri dalam menentukan patokan kemampuannya.

Berdasarkan hal tersebut, mengingat perkembangan teknologi terutama di cabang olahraga sepakbola yang begitu pesat, maka perlu adanya inovasi dalam tes keterampilan sepakbola untuk mempermudah pelatih dan praktisi sepakbola dalam hal membuat kesimpulan setelah pemain melakukan tes berdasarkan data yang empiris. Inovasi dalam hal teknologi perangkat lunak (aplikasi) yang berbasis web, khususnya dalam pengumpulan dan teknik analisa data melalui komputerisasi, sehingga akan mempermudah pekerjaan, seperti: Pengolahan data lebih cepat, pengambilan keputusan secara cepat, menghemat waktu, dan biaya.

\section{METODE}

Penelitian ini merupakan penelitian pengembangan atau Research and Development adalah metode penelitian yang digunakan untuk menghasilkan produk tertentu dan menguji keefektifan produk tersebut. Menurut Borg \& Gall (2007, p.569) penelitian R \& D adalah "Educational Research and Development $(R \& D)$ is a process used to develop and validate products.In contrast, the goal of educational research is not to develop products, but rather to discover new knowledge (through basic research)".

Prosedur penelitian dan pengembangan ini menggunakan langkah-langkah Borg \& Gall (2007, p.775-776) yang disederhanakan. Desain penelitian pengembangan model pengembangan Borg dan Gall kemudian diubah dengan lebih sederhana melibatkan lima langkah utama: (1) studi pendahuluan dan pengumpulan informasi, (2) desain produk awal, (3) validasi ahli/revisi, (4) ujicoba lapangan skala kecil/revisi, (5) uji coba skala besar dan produk akhir.

Target/subjek penelitian ini yaitu untuk uji coba skala kecil diperoleh dari Pelatih Kelas Khusus Olahraga (KKO) cabang sepakbola dan Pelatih Sekolah Sosial Olahraga (SSO) Real Madrid UNY dengan subjek 8 orang pelatih. Uji coba skala besar data diperoleh dari Pelatih dari 
berbagai kategori umur pemain muda melibatkan 25 Pelatih Sekolah Sepakbola (SSB) yang ada di Yogyakarta dengan Subjek Pelatih minimal lulusan dari prodi kepelatihan yang melatih Kelas Khusus Olahraga (KKO) dan Sekolah Sepakbola (SSB) atau minimal berlisensi D sebanyak 25 orang.

Untuk menghasilkan model pengembangan yang berkualitas diperlukan instrumen yang mampu menggali data yang diperlukan untuk mengumpulkan data pada penelitian ini. Instrumen yang digunakan yaitu ada dua, yang pertama untuk menilai aplikasi dan yang kedua untuk menilai buku panduan. Instrumen berupa kuisioner untuk ahli materi, ahli media, dan untuk pelatih.

Teknik analisis data yang dilakukan dalam penelitian ini yaitu analisis deskriptif kuantitatif dan analisis deskriptif. Analisis deskriptif kuantitatif dilakukan untuk menganalisis datadata berikut: (1) data skala nilai hasil penilaian terhadap draf model, (2) data hasil tes keterampilan sepakbola untuk menyusun norma, (3) data hasil penilaian produk, (5) data hasil uji coba skala kecil dan (6) data uji coba lapangan skala besar. Sementara analisis deskriptif kualitatif dilakukan terhadap: (1) data kekurangan dan masukan terhadap aplikasi sebelum uji coba maupun setelah uji coba di lapangan.

\section{HASIL DAN PEMBAHASAN}

\section{Analisis Pendahuluan}

Studi pendahuluan dilakukan untuk mengumpulkan data/analisis kebutuhan yang didapat melalui studi lapangan dan studi literatur. Analisis melalui studi lapangan dilakukan dengan menyebar angket yang disebar ke 33 pelatih sekolah sepakbola yang ada di wilayah Kabupaten Kota Yogyakarta dan Kabupaten Sleman. Berikut hasil studi pendahuluan menggunakan angket survei: sebanyak $100 \%$ pelatih dapat mengoperasikan komputer dan smartphone, sebanyak $100 \%$ pelatih dapat mengakses internet melalui komputer dan smartphone, sebanyak $100 \%$ pelatih menggunakan komputer, neetbook, dan smartphone dalam membantu pengolahan data tes, sebanyak $87 \%$ pelatih menyatakan tidak kesulitan mengolah data sebagian tes keterampilan sepakbola, sebanyak $97 \%$ melakukan tes dan pengukuran pretest terhadap siswa pada saat seleksi atau sebelum mengikuti program latihan, sebanyak $97 \%$ pelatih melakukan tes dan pengukuran posttest keterampilan siswa/pemain setelah siswa selesai mengikuti program latihan, sebanyak $100 \%$ pelatih menyatakan sangat perlu pengembangan seperti aplikasi konversi data hasil tes ke dalam tabel untuk membantu memudahkan konversi (pengkategorian) hasil tes, sebanyak $100 \%$ pelatih menyatakan setuju dengan pengembangan aplikasi ini, sehingga di masa depan akan tercipta norma baku keterampilan sepakbola sesuai dengan tingkatan usia yang lebih luas.

\section{Perancangan Alikasi atau Draf Awal}

Perancangan draf awal terdiri atas: perancangan operasi program, menu, dan penilaian ahli. Validasi dilakukan dengan menyampaikan draf produk awal rancangan program dan buku panduan, dengan disertai lembar penilaian dengan skala nilai yang di dalamnya terdapat masukan, saran, serta revisi dari para ahli. Hasil penilaian berupa skala nilai untuk kebenaran isi konsep materi dan aspek media dalam aplikasi yang akan dibuat dengan menggunakan skala likert dengan pilihan 5 kategori. Hasil penilaian ahli terhadap draf model disajikan pada Tabel 1.

Tabel 1. Data Hasil Validasi Draf terhadap Apilkasi

\begin{tabular}{cccc}
\hline No. & Pakar & \% & Kategori \\
\hline 1. & Ahli Materi & 74,28 & Baik \\
2. & Ahli Media & 80 & Baik \\
\hline
\end{tabular}

Tabel 1 menunjukkan penilaian ahli materi menunjukkan persentase sebesar 74,28\% masuk dalam kategori baik dan ahli media menunjukkan persentase sebesar $80 \%$ masuk dalam kategori baik. Hal ini menunjukkan penilaian kedua ahli terhadap program yang dibuat telah layak untuk dikembangkan dengan perbaikan/revisi.

Data hasil evaluasi draf buku panduan Aplikasi Tes Keterampilan Sepakbola (Soccer Skill Test) Berbasis Web oleh ahli materi dapat dipaparkan pada Tabel 2.

Tabel 2. Data Hasil Validasi Draf terhadap Buku Panduan

\begin{tabular}{cccc}
\hline No. & Pakar & $\%$ & Kategori \\
\hline 1. & Ahli Materi & 75,78 & Baik \\
2. & Ahli Media & 70,52 & Baik \\
\hline
\end{tabular}

Tabel 2 menunjukkan penilaian ahli materi menunjukkan persentase sebesar 75,78\% masuk dalam kategori baik dan ahli media menunjukkan persentase sebesar 70,52\% masuk dalam kategori baik. Hal ini menunjukkan penilaian kedua ahli terhadap Buku panduan 
Aplikasi yang dibuat telah layak untuk dikembangkan dengan perbaikan/revisi.

\section{Penyusunan Norma Baku Item Tes}

Penyusunan norma baku tes keterampilan sepakbola dilakukan dengan melakukan tes pada sampel siswa Kelas Khusus Olahraga (KKO) cabang sepakbola kelompok usia 13-15 tahun berjumlah 84 siswa. Sampel dalam penyusunan norma item tes keterampilan sepakbola terdiri atas siswa SMP Negeri 3 Sleman sebanyak 50 siswa dan siswa SMP Negeri 13 Yogyakarta sebanyak 34 siswa. Norma baku tes keterampilan sepakbola disajikan pada Tabel 3 sampai Tabel 9.

Tabel 3. Tes Keterampilan Menggiring

\begin{tabular}{lcc}
\hline No. & Rentang Nilai & Kategori \\
\hline 1. & $17,88<$ & Sangat Kurang \\
2. & $16,69-17,880,5$ & Kurang \\
3. & $15,50-16,69$ & Cukup Baik \\
4. & $14,31-15,50$ & Baik \\
5. & $\leq 14,31$ & Sangat Baik \\
\hline
\end{tabular}

Tabel 4. Tes Passing-Control

\begin{tabular}{lcc}
\hline No. & Rentang Nilai & Kategori \\
\hline 1. & $14,23<$ & Sangat Baik \\
2. & $12,62-14,23$ & Baik \\
3. & $11,01-12,62$ & Cukup Baik \\
4. & $09,41-11,01$ & Kurang \\
5. & $\leq 09,41$ & Sangat Kurang \\
\hline
\end{tabular}

Tabel 5. Tes Keterampilan Shooting

\begin{tabular}{lcc}
\hline No. & Rentang Nilai & Kategori \\
\hline 1. & $\geq 131$ & Sangat baik \\
2. & $111-130$ & Baik \\
3. & $91-110$ & Cukup \\
4. & $71-90$ & Kurang \\
5. & $\leq 70$ & Sangat Kurang \\
\hline
\end{tabular}

Tabel 6. Tes Keterampilan Passing Lambung

\begin{tabular}{ccc}
\hline No. & Rentang Nilai & Kategori \\
\hline 1. & $\geq 321$ & Sangat baik \\
2. & $241-320$ & Baik \\
3. & $161-240$ & Cukup \\
4. & $81-160$ & Kurang \\
5. & $\leq 80$ & Sangat Kurang \\
\hline
\end{tabular}

Tabel 7. Tes Keterampilan Passing Lambung

\begin{tabular}{ccc}
\hline No. & Rentang Nilai & Kategori \\
\hline 1. & $\geq 321$ & Sangat baik \\
2. & $241-320$ & Baik \\
3. & $161-240$ & Cukup \\
4. & $81-160$ & Kurang \\
5. & $\leq 80$ & Sangat Kurang \\
\hline
\end{tabular}

Hasil uji validitas dan reliabilitas masingmasing item tes keterampilan sepakbola: (1) Tes Keterampilan Menggiring (Dribbling) validitas sebesar 0,979 dan reliabilitas 0,983, (2) Tes Keterampilan Passing-Control validitas sebesar 0,766 dan reliabilitas 0,811, (3) Keterampilan Shooting validitas sebesar 0,872 dan reliabilitas 0,890, (4) Tes Keterampilan Passing Lambung validitas sebesar 0,874 dan reliabilitas 0,898, (5) Tes Keterampilan Juggling validitas sebesar 0,971 dan reliabilitas 0,970, (6) Tes Keterampilan Heading validitas sebesar 0,989 dan reliabilitas 0,992 .

Tabel 8. Tes Keterampilan Juggling

\begin{tabular}{ccc}
\hline No. & Rentang Nilai & Kategori \\
\hline 1. & $94,44<$ & Sangat Baik \\
2. & $78,88-94,44$ & Baik \\
3. & $63,31-78,88$ & Cukup Baik \\
4. & $47,75-63,31$ & Kurang \\
5. & $\leq 47,75$ & Sangat Kurang \\
\hline
\end{tabular}

Tabel 9. Tes Keterampilan Heading

\begin{tabular}{ccc}
\hline No. & Rentang Nilai & Kategori \\
\hline 1. & $36,46<$ & Sangat Baik \\
2. & $30,76-36,46$ & Baik \\
3. & $25,05-30,76$ & Cukup Baik \\
4. & $19,35-25,05$ & Kurang \\
5. & $\leq 19,35$ & Sangat Kurang \\
\hline
\end{tabular}

\section{Hasil Uji Coba Produk}

\section{Penilaian Ahli Materi}

Ahli materi memberikan penilaian terhadap produk yang dikembangkan serta memberikan saran perbaikan untuk selanjutnya dilakukan revisi produk. Data hasil penilaian produk dihitung dari jumlah skor maksimal butir dan skor riil yang didapat kemudian dikonversikan ke dalam tabel persentase. Hasil penilaian ahli materi terhadap produk dan buku panduan aplikasi tes keterampilan sepakbola (soccer skill test) berbasis web dapat dilihat di Tabel 10:

Tabel 10. Data Hasil Penilaian Ahli Materi terhadap Produk dan Buku Panduan

\begin{tabular}{lcc}
\hline \multicolumn{1}{c}{ Penilaian } & \% & Kategori \\
\hline Penilaian Produk & 94,28 & Sangat Baik \\
Buku Panduan & 93,08 & Sangat Baik \\
\hline
\end{tabular}

Penilaian Ahli Media

Ahli media memberikan penilaian terhadap produk yang dikembangkan serta memberikan saran perbaikan untuk selanjutnya dilakukan revisi produk. Hasil penilaian ahli media terhadap produk dan buku panduan aplikasi tes 
keterampilan sepakbola (soccer skill test) berbasis web dapat dilihat pada Tabel 11.

Tabel 11. Data Hasil Penilaian Ahli Media terhadap Produk dan Buku Panduan

\begin{tabular}{clcc}
\hline Pakar & \multicolumn{1}{c}{ Penilaian } & $\%$ & Kategori \\
\hline Pakar 1 & Penilaian Produk & 85,38 & Sangat Baik \\
& Buku Panduan & 90,52 & Sangat Baik \\
Pakar 2 & Penilaian Produk & 80,76 & Sangat Baik \\
& Buku Panduan & 75,78 & Baik \\
\hline
\end{tabular}

Hasil Uji Coba Skala Kecil

Pelaksanaan uji coba skala kecil dilaksanakan dengan cara mendemontrasikan kepada 3 pelatih Kelas Khusus Olahraga (KKO) dan 5 Pelatih Sepakbola (SSB) yang dipilih secara acak.

Proses pelaksanaan uji kelayakan produk ini adalah dengan mendemontrasikan cara kerja aplikasi tes keterampilan sepakbola yang dijalankan di laptop/komputer serta memberikan buku panduan sebagai pendamping, selanjutnya pelatih diberi waktu untuk mengoperasikan. Kemudian untuk mengetahui kualitas produk yang dikembangkan, peneliti memberikan lembar penilaian kepada pelatih. Selama proses pengisian lembar penilaian, pelatih masih dapat melihat kembali aplikasi tes keterampilan sepakbola (soccer skill test) berbasis web.

Pada Tabel 12 disajikan hasil penilaian pelatih terhadap produk aplikasi tes keterampilan sepakbola (soccer skill test) berbasis web pada uji coba kelompok kecil:

Tabel 12. Data Hasil Penilaian Pelatih terhadap Produk pada Uji Coba Skala Kecil

\begin{tabular}{lcc}
\hline \multicolumn{1}{c}{ Pakar } & \% & Kategori \\
\hline Tampilan & 88,33 & Sangat Baik \\
Isi/ Materi & 83,75 & Sangat Baik \\
Penggunaan & 87,73 & Sangat Baik \\
Keseluruhan & $\mathbf{8 7 , 5}$ & Sangat Baik \\
\hline
\end{tabular}

Penilaian pelatih terhadap produk aplikasi tes keterampilan sepakbola (soccer skill test) berbasis $w e b$ pada aspek tampilan menunjukkan persentase sebesar 87,5\% masuk dalam kategori sangat baik. Hal tersebut menunjukkan penilaian pelatih terhadap produk aplikasi tes keterampilan sepakbola (soccer skill test) berbasis web pada uji coba skala kecil telah layak dengan perbaikan/revisi sesuai saran, dan dapat dilanjutkan dengan uji coba skala yang lebih luas.

Pada Tabel 13 disajikan hasil penilaian pelatih terhadap buku panduan aplikasi tes keterampilan sepakbola (soccer skill test) berbasis web pada uji coba kelompok kecil:
Tabel 13. Data Hasil Penilaian Pelatih terhadap Buku Panduan pada Uji Coba Skala Kecil

\begin{tabular}{lcc}
\hline \multicolumn{1}{c}{ Pakar } & \% & Kategori \\
\hline Tampilan & 82,50 & Sangat Baik \\
Isi/ Materi & 86,67 & Sangat Baik \\
Penggunaan & 86,67 & Sangat Baik \\
Keseluruhan & $\mathbf{8 5 , 7 9}$ & Sangat Baik \\
\hline
\end{tabular}

Penilaian pelatih terhadap buku panduan aplikasi tes keterampilan sepakbola (soccer skill test) berbasis web pada aspek tampilan menunjukkan persentase sebesar $85,79 \%$ masuk dalam kategori sangat baik. Hal tersebut menunjukkan penilaian pelatih terhadap buku panduan aplikasi tes keterampilan sepakbola (soccer skill test) berbasis web pada uji coba skala kecil telah layak dengan perbaikan/revisi sesuai saran, dan dapat dilanjutkan dengan uji coba skala yang lebih luas.

\section{Uji Coba Skala Besar}

Pelaksanaan uji coba skala besar dilaksanakan dengan cara mendemontrasikan Pelatih Sepakbola (SSB) di Kabupaten Kota Yogyakarta dan di Kabupaten Sepakbola berjumlah 25 orang pelatih yang dipilih secara acak.

Proses pelaksanaan uji lapangan skala produk ini adalah dengan mendemontrasikan cara kerja aplikasi konversi hasil tes keterampilan sepakbola yang dijalankan di laptop/komputer serta memberikan buku panduan sebagai pendamping, selanjutnya pelatih diberi waktu untuk mencoba mengoperasikan. Kemudian untuk mengetahui kualitas produk yang dikembangkan, peneliti memberikan lembar penilaian kepada pelatih. Selama proses pengisian lembar penilaian, pelatih masih dapat melihat kembali aplikasi tes keterampilan sepakbola (soccer skill test) berbasis web

Pada Tabel 14 disajikan hasil penilaian pelatih terhadap produk aplikasi tes keterampilan sepakbola (soccer skill test) berbasis web pada uji coba kelompok besar:

Tabel 14. Data Hasil Penilaian Pelatih terhadap Produk pada Uji Coba Skala Besar

\begin{tabular}{lcc}
\hline \multicolumn{1}{c}{ Pakar } & \% & Kategori \\
\hline Tampilan & 84,80 & Sangat Baik \\
Isi/ Materi & 82,4 & Sangat Baik \\
Penggunaan & 85,45 & Sangat Baik \\
Keseluruhan & $\mathbf{8 4 , 9 2}$ & Sangat Baik \\
\hline
\end{tabular}

Penilaian pelatih terhadap produk aplikasi tes keterampilan sepakbola (soccer skill test) berbasis $w e b$ pada aspek tampilan menunjukkan persentase sebesar $84,92 \%$ masuk dalam kate- 
gori sangat baik. Hal tersebut menunjukkan penilaian pelatih terhadap produk aplikasi tes keterampilan sepakbola (soccer skill test) berbasis web pada uji coba skala besar telah layak dengan perbaikan/revisi sesuai saran, dan dapat dijadikan sebagai produk akhir.

Berikut disajikan hasil penilaian pelatih terhadap buku panduan aplikasi tes keterampilan sepakbola (soccer skill test) berbasis web pada uji coba kelompok besar:

Tabel 15. Data Hasil Penilaian Pelatih terhadap Buku Panduan pada Uji Coba Skala Besar

\begin{tabular}{lcc}
\hline \multicolumn{1}{c}{ Pakar } & \% & Kategori \\
\hline Tampilan & 82,20 & Sangat Baik \\
Isi/ Materi & 85,47 & Sangat Baik \\
Penggunaan & 82,93 & Sangat Baik \\
Keseluruhan & $\mathbf{8 4 , 3 8}$ & Sangat Baik \\
\hline
\end{tabular}

Penilaian pelatih terhadap buku panduan aplikasi tes keterampilan sepakbola (soccer skill test) berbasis web pada aspek tampilan menunjukkan persentase sebesar 84,38 \% masuk dalam kategori sangat baik. Hal tersebut menunjukkan penilaian pelatih terhadap buku panduan aplikasi tes keterampilan sepakbola (soccer skill test) berbasis web pada uji coba skala besar telah layak dengan perbaikan/revisi sesuai saran, dan dapat dijadikan sebagai produk akhir.

Revisi Produk

Revisi produk dilakukan sebanyak dua kali, yaitu: (1) revisi I dilakukan pada tahap validasi dan (2) revisi II dilakukan setelah uji kelayakan produk. Revisi-revisi ini didasarkan pada data saran dan masukan dari para pakar ahli materi dan ahli media. Adapun hasil revisi tersebut dapat dilihat pada Tabel 16.

Berdasarkan saran dan perbaikan dari tahap validasi pakar maka selanjutkan peneliti melakukan revisi terhadap produk awal sebelum produk diujicobakan pada tahap berikutnya yaitu uji skala kecil. Peneliti mengkaji masukanmasukan dari para ahli untuk penyempurnaan produk. Masukan-masukan dari ahli sangat membantu peneliti untuk memperbaiki draf atau produk yang akan dihasilkan nantinya.

Data yang digunakan untuk melakukan revisi kedua ini merupakan data saran dan masukan yang didapat peneliti setelah melakukan uji coba skala kecil. Berikut ini merupakan data saran dan masukan yang diperoleh setelah melakukan uji coba skala kecil. Masukan terhadap model pada uji coba skala kecil disajikan pada Tabel 17.
Tabel 16. Masukan dan Saran pada Draf Awal

\begin{tabular}{cl}
\hline Ahli & \multicolumn{1}{c}{ Kategori } \\
\hline Ahli & Gambar tes sepakbola diambil dari \\
Media 1 & ujicoba \\
& Dicantumkan kelompok usia di masing- \\
& masing tes \\
& Diberi petunjuk untuk log in ke aplikasi \\
& Cover warna buku dibuat lebih menarik \\
& Konsistensi dalam penulisan. \\
& Tujuan Tes untuk usia yang \\
& direkomendasikan \\
& Ditambah halaman untuk admin beserta \\
& kontak yang bisa dihubungi \\
& Tampilan input skor hasil tes dibuat lebih \\
& simpel \\
Ahli & Gambar Home diganti dari dokumen \\
pribadi tes & \\
& Nama aplikasi dipertimbangkan “aplikasi \\
& konversi hasil tes" \\
Ahli & Gambar Tes David Lee diperbaiki lagi \\
Materi & Sudah sesuai dengan referensi \\
& Dimasa datang bisa ditambah dengan tes \\
& yang lain dan dibuat aplikasi offline \\
\hline
\end{tabular}

Tabel 17. Masukan dan Saran pada Uji Coba Skala Kecil

\begin{tabular}{cl}
\hline No. & \multicolumn{1}{c}{ Masukan dan Saran } \\
\hline 1. & Segera disebarkan ke seluruh SSB \\
2. & Inovasi yang sangat baik di dunia sepakbola \\
3. & Gambar di Buku diambil dari tes \\
4. & Sangat membantu pelatih dalam mengolah data \\
& tes
\end{tabular}

Berdasarkan saran dan perbaikan dari tahap uji coba skala kecil, maka selanjutkan peneliti akan melakukan revisi terhadap produk untuk kemudian diujicobakan pada tahap skala besar.

\section{Kajian Produk Akhir}

Langkah berikutnya setelah draf dinyatakan layak untuk dikembangkan adalah menterjemahkan draf ke dalam program aplikasi tes keterampilan sepakbola (Soccer Skill Test) Berbasis Web. Tahap desain merupakan tahap penyusunan kerangka produk sekaligus terkait juga dengan fungsi-fungsinya. Pada produk Aplikasi Tes Keterampilan Sepakbola (Soccer Skill Test) Berbasis Web meliputi beberapa bagian dan halaman, yakni halaman menu, halaman konversi hasil tes keterampilan sepakbola, halaman kontak admin. Pada tahap ini produk dibuat hingga review ahli media dan ahli materi serta revisi. Berikut ini uraian dari masing-masing halaman produk:

Cara membuka situs: untuk memulai akses terhadap aplikasi konversi ini: (1) Bukalah 
Aplikasi Konversi Tes sepakbola melalui web browser (IE atau Mozila Firefox atau lainnya) dengan alamat url sebagai berikut: http://www.soccertest-ES-515.com, alamat ini merupakan versi "bheta". (2) Kemudian tekan Enter pada tombol keyboard atau klik tombol Go pada browser. (2) Akan muncul tampilan halaman depan aplikasi konversi tes sepakbola.

Panduan Aplikasi beserta buku panduan aplikasi tes keterampilan sepakbola (soccer skill test) berbasis web sebagai panduan yang digunakan untuk pelatih dan manjaemen klub sepakbola telah selesai dikembangkan pada tahap evaluasi dan uji coba yang dilalui yaitu validasi ahli materi, ahli media, uji skala kecil, dan uji skala besar. Pembahasan kajian produk akhir pengembangan Aplikasi beserta buku panduan aplikasi tes keterampilan sepakbola (soccer skill test) berbasis web ini merupakan hasil konfirmasi antar kajian teori dengan hasil penelitian yang diperoleh.

Penilaian terhadap produk yang telah selesai dikembangkan yang berupa "Aplikasi Tes Keterampilan Sepakbola (Soccer Skill Test) Berbasis Web" menunjukkan hasil yang positif. Beberapa tampilan produk yang sudah mengalami revisi dari ahli materi, ahli media dan tahap uji coba bisa dilihat pada lampiran. Setelah selesai menjadi produk akhir dilakukan diseminasi pemasalan dengan cara memberikan buku kepada pelatih dan melakukan bedah buku secara terbatas.

Pengembangan Aplikasi Tes Keterampilan Sepakbola (Soccer Skill Test) Berbasis Web berdasarkan analisis kebutuhan adalah untuk membantu memudahkan pelatih sepakbola dalam proses pengolahan data atau konversi data hasil tes keterampilan sepakbola yang tersiri dari tujuh item tes. Hal ini sesuai dengan hasil obesrvasi dilapangan yang menyebar angket angket yang disebar ke 33 pelatih Kelas Khusus Olahraga (KKO) cabang sepakbola dan pelatih Sekolah Sepakbola (SSB), sebanyak $100 \%$ pelatih dapat mengoperasikan komputer dan smartphone, sebanyak $100 \%$ pelatih dapat mengakses internet melalui komputer dan smartphone, sebanyak $100 \%$ pelatih menggunakan komputer, neetbook, dan smartphone dalam membantu pengolahan data tes, sebanyak $87 \%$ pelatih menyatakan tidak kesulitan mengolah data sebagian tes keterampilan sepakbola, sebanyak $97 \%$ melakukan tes dan pengukuran pretest terhadap siswa pada saat seleksi atau sebelum mengikuti program latihan, sebanyak $97 \%$ pelatih melakukan tes dan pengukuran posttest keterampilan siswa/pemain setelah siswa selesai mengikuti program latihan, sebanyak $100 \%$ pelatih menyatakan sangat perlu pengembangan seperti aplikasi konversi data hasil tes ke dalam tabel untuk membantu memudahkan konversi (pengkategorian) hasil tes, sebanyak $100 \%$ pelatih menyatakan setuju dengan pengembangan aplikasi ini, sehingga dimasa depan akan tercipta norma baku keterampilan sepakbola sesuai dengan tingkatan usia.

Dari data tersebut kemudian dikembangkan sebuah Aplikasi Tes Keterampilan Sepakbola (Soccer Skill Test) Berbasis Web. Pengembangan program ini merupakan produk yang telah layak digunakan untuk para pelatih sepakbola sebagai alat untuk mengolah hasil tes secara cepat, tepat dan efisien. Sehingga akan membantu pelatih atau staff manajemen klub dalam proses seleksi pemain monitoring pembinaan pemain sepakbola. Hal ini diperkuat oleh pernyataan Pope \& Forster (2009, p. 96) The use of such technology (biomechanics) with a suitable user interface will empower the coach to gain insight into existing performance level more readily and conveniently. Dapat diartikan bahwa penggunaan teknologi dalam hal ini cabang sepakbola dapat memberikan keleluasaan kepada pelatih untuk memperoleh level kemampuan yang ada dengan mudah dan tepat. Selanjutnya penelitian dan pengembangan dalam bentuk multimedia yang dilakukan oleh Fitriadi \& Rachman (2014, p. 9) mengindindikasikan bahwa multimedia dapat mempermudah pekerjaan.

Dalam Aplikasi Tes Keterampilan Sepakbola (Soccer Skill Test) Berbasis Web ada beberapa menu pokok yaitu: (1) Menu Home. (2) Menu Panduan Tes dan Konversi Hasil Tes Keterampilan Sepakbola yang bisa di input secara individu maupun data Excel. (3) Aplikasi konversi hasil tes terdiri dari 7 item tes keterampilan sepakbola yaitu: tes dribbling, passingcontrol, shooting, passing lambung, juggilng, heading, david lee (Subagyo Irianto). (3) Menu contak admin.

Berdasarkan penilaian para ahli, revisi, ujicoba lapangan (skala kecil dan skala besar), pengembangan "Aplikasi Tes Keterampilan Sepakbola (Soccer Skill Test) Berbasis Web" diperoleh hasil yang ditarik kesimpulan bahwa Aplikasi Tes Keterampilan Sepakbola (Soccer Skill Test) Berbasis Web ini dinilai layak. 


\section{SIMPULAN}

Dari hasil analisis data penilaian para ahli, dan pelatih, dan pemain, dapat diambil simpulan bahwa langkah-langkah pengembangan Aplikasi Tes Keterampilan Sepakbola (Soccer Skill Test) Berbasis Web yaitu dimulai dari tahap: (1) Melakukan studi pendahuluan dan pengumpulan informasi, (2) Mengembangkan desain produk awal (3) Validasi ahli dan revisi (4) Ujicoba lapangan skala kecil dan revisi produk (5) Uji coba lapangan skala besar dan produk akhir. Aplikasi Tes Keterampilan Sepakbola (Soccer Skill Test) Berbasis Web" ada beberapa menu pokok yaitu: (1) Menu Home, (2) Menu Panduan Tes dan Konversi Hasil Tes Keterampilan Sepakbola yang bisa di input secara individu maupun data Excel, (3) Aplikasi konversi hasil tes terdiri dari 7 item tes keterampilan sepakbola yaitu: tes dribbling, passing-control, shooting, passing lambung, juggilng, heading, david lee (Subagyo Irianto), (4) Menu contak admin.

Aplikasi Tes Keterampilan Sepakbola (Soccer Skill Test) Berbasis Web yang dikembangkan layak digunakan oleh pelatih untuk mengolah hasil data tes keterampilan sepakbola. Hal ini ditunjukkan dengan hasil uji skala besar pada aspek tampilan menunjukkan persentase sebesar 82,20\% masuk dalam kategori sangat baik, aspek isi/materi menunjukkan persentase sebesar 85,47 \% masuk dalam kategori sangat baik, dan aspek penggunaan menunjukkan persentase sebesar 82,93\% masuk dalam kategori sangat baik.

Berdasarkan hasil penelitian pengembangan Aplikasi Tes Keterampilan Sepakbola (Soccer Skill Test) Berbasis Web ini diharapkan dapat memberikan manfaat dan saran dari beberapa pihak: (1) Bagi peneliti selanjutnya, pengembangan "Aplikasi Tes Keterampilan Sepakbola (Soccer Skill Test) Berbasis Web" ini dapat menjadi pedoman untuk penelitian selanjutnya. (2) Aplikasi Tes Keterampilan Sepakbola (Soccer Skill Test) Berbasis Web dapat dikembangkan lebih lanjut dengan materi yang lebih lengkap.

\section{DAFTAR PUSTAKA}

Barreira, D. (2013). SoccerEye: A software solution to observe and record behaviours in sport settings. The Open Sports Science Journal. Porto: University of Porto, 6, Page 47-55.

Bompa, T. O. (1994). Theory and methodology of training. (terjemahan). Bandung: Program Pascasarjana Universitas Padjajaran Bandung.

Bompa, T. O. (2009). Theory and methodology of training. Toronto: Mozaic Press.

Borg, W.R. \& Gall, M.D. (2007). Educational research: An introduction. New York \& London: Longman.

Fitriadi, A., \& Rachman, H. (2014). Pengembangan multimedia pendidikan jasmani materi budaya hidup sehat untuk sekolah menengah atas. Jurnal Keolahragaan, 2(1), 1 - 10. doi:http://dx.doi.org/10.21831/jk.v2i1.256 5

Harsuki. (2003). Perkembangan olahraga terkini kajian para pakar. Jakarta: Rajagrafindo Persada

Luxbacher, J.A. (2011). Sepakbola langkahlangkah menuju sukses. Jakarta: PT. Rosda Jaya Putra.

McLeod, P. (2008). Sistem informasi manajemen. Salemba. Jakarta.

Pope, K.L., \& Forster (2009). Digital sport for performance enhancement and competitive evolution: intelegent gaming technologies. Hershey, PA: IGI Global.

Rohmat. (2014). Dongkrak prestasi olahraga RI lewat penguasaan iptek retrived from: http://sports.

sindonews.com/read/889565/51/dongk rak-prestasi-olahraga-ri-lewatpenguasaan-iptek-1407573276

Rosandich. T.J. (2011). Information technology and sports: looking toward web 3.0. United States: The sport journal ISSN: 1543-9518. 